\title{
Preface and Acknowledgements
}

This book is the result of my scholarly journey across the vast area of the Eurasian continent in search of the origin of chinoiserie. My love of chinoiserie stems from my obsession with the image of China, which has touched my heart since I chanced upon Chinese pagodas in Meissen wares some twenty years ago. This led me first to wander up and down Europe and the Middle East as a traveller to discover the essence of this artistic and cultural phenomenon, eventually to choose chinoiserie in Iranian art under the Mongols as the topic of my doctoral research and finally to turn my brainchild into a book. To challenge such a fascinating but laborious subject was not an easy task: it required perseverance, stamina and even courage. The topic did, however, gratify my research desire so strongly that I am convinced that I shall never lose my passion and enthusiasm to continue its further study.

It did not take me so long to find out that chinoiserie is not just an art-historical matter. The Meissen pagodas and other sinicising modes, such as Chinese dragons found in the art of Mongol Iran, are deeply rooted in a vital aspect of the human psyche - curiosity. Indeed, chinoiserie conveys positive signals of understanding other cultures, as well as of generating new ideas. While the term 'Islamic chinoiserie' in itself is somewhat contradictory, particularly for those who have a clichéd view of Islamicness in Islamic art and exoticism in chinoiserie, the outcome of this amalgamation was, which I hope that this book proves, a happy, eternal marriage.

My first debt of gratitude is to Professor Robert Hillenbrand for the advice, comments and humour that he offered me during my doctoral research in Edinburgh. It is therefore a distinct honour to publish this book in the Edinburgh Studies of Islamic Art under his editorship. I am also indebted to Edinburgh University Press, especially to Mrs Nicola Ramsey, who commissioned this book, and to Mr Eddie Clark, who guided the book through production with much patience.

My research was made a pleasure through the help and encouragement of numerous individuals, and my scholarly debts are found in the notes and the bibliography. Any mistakes are, needless to say, 
solely my responsibility. I am particularly grateful to Professor Bernard O'Kane for his invaluable comments on my doctoral dissertation, from which this book grew, and to three Chinese art lecturers in Edinburgh while I was undertaking this research, namely Dr Anita Chung, Dr Hongxing Zhang and Dr Hsueh-man Shen, for their help and wisdom. My special thanks also go to Professor Mayumi Tsuruoka for her continuous encouragement throughout the past fifteen years.

The writing of this book was made possible through research grants from the following organisations: the Barakat Trust, University of Oxford; the Gen Foundation, London; the Iran Heritage Foundation, London; the Kashima Art Foundation, Japan; the Overseas Research Students Scheme; and the School of Arts, Culture and Environment (formerly the Faculty of Arts), University of Edinburgh. My postdoctoral research at the Institute for Advanced Studies in the Humanities, University of Edinburgh, and the Warburg Institute, University of London, gave me wonderful opportunities to rethink the problem of chinoiserie from an inter disciplinary point of view. Equally valuable was my professional experience at the University of Edinburgh, the Museum of Islamic Art in Doha and the Art Institute of Chicago. I also wish to express my gratitude to the following institutions, which gave me permission to work on their collections: the Bibliothèque nationale de la France, Paris; the Freer and Sackler Gallery of Art, Washington, DC; the Special Collections, Edinburgh University Library; the Staatsbibliothek zu Berlin - Stiftung Preussischer Kulturbesitz, Orientabteilung, Berlin); and the Topkap1 Saray Palace Library, Istanbul. The illustrations are acknowledged individually on the captions, with a special indebtedness to the alSabah Collection, Dar al-Athar al-Islamiyya, Kuwait, for its generous grant. Every effort has been made to trace copyright-holders, but if any have been inadvertently overlooked, the publisher will be pleased to make the necessary arrangements at the first opportunity.

I express my sincere thanks to my parents and sister for their longterm support, and the same debt goes to Mr Roy and Mrs Jean Faulkner, my 'Scottish parents'. Special thanks are also due to my friends from all over the world for their help and encouragement, and, above all, to Thorsten Hanke, who is behind the completion of this project. 